\title{
Cold spot microrefugia hold the key to survival for Brazil's critically endangered Araucaria tree
}

Article

Accepted Version

Wilson, O. J., Walters, R. J., Mayle, F. E., Lingner, D. V. and Vibrans, A. C. (2019) Cold spot microrefugia hold the key to survival for Brazil's critically endangered Araucaria tree.

Global Change Biology, 25 (12). pp. 4339-4251. ISSN 13652486 doi: https://doi.org/10.1111/gcb.14755 Available at https://centaur.reading.ac.uk/85187/

It is advisable to refer to the publisher's version if you intend to cite from the work. See Guidance on citing.

To link to this article DOI: http://dx.doi.org/10.1111/gcb.14755

Publisher: Wiley

All outputs in CentAUR are protected by Intellectual Property Rights law, including copyright law. Copyright and IPR is retained by the creators or other copyright holders. Terms and conditions for use of this material are defined in the End User Agreement.

www.reading.ac.uk/centaur 
Central Archive at the University of Reading

Reading's research outputs online 


\section{Cold spot microrefugia hold the key to}

\section{survival for Brazil's Critically Endangered}

\section{Araucaria tree}

Running title: Microrefugia for Brazil's Araucaria tree

Oliver J. Wilson ${ }^{\mathrm{a} *}$ (https://orcid.org/0000-0002-1834-7542)

Richard J. Walters ${ }^{\mathrm{b}, \mathrm{c}}$

Francis E. Mayle (https://orcid.org/0000-0001-9208-0519)

Débora V. Lingner ${ }^{d}$ (https://orcid.org/0000-0002-6391-9343)

Alexander C. Vibrans ${ }^{d}$ (https://orcid.org/0000-0002-8789-5833)

${ }^{\text {a }}$ School of Archaeology, Geography and Environmental Sciences, University of Reading, UK

${ }^{\mathrm{b}}$ School of Biological Sciences, University of Reading, UK

${ }^{c}$ Centre for Environmental and Climate Research, Lund University, Sweden

${ }^{\mathrm{d}}$ Department of Forest Engineering, Universidade Regional de Blumenau, Santa Catarina, Brazil

* Corresponding author: o.j.wilson@reading.ac.uk, +44 7854603024

This article has been accepted for publication and undergone full peer review but has not been through the copyediting, typesetting, pagination and proofreading process, which may lead to differences between this version and the Version of Record. Please cite this article as doi: $10.1111 / \mathrm{gcb} .14755$

This article is protected by copyright. All rights reserved. 


\section{Abstract}

Brazil's Araucaria tree (Araucaria angustifolia) is an iconic living fossil and a defining element of the Atlantic Forest global biodiversity hotspot. But despite more than two millennia as a cultural icon in southern Brazil, Araucaria is on the brink of extinction, having lost $97 \%$ of its extent to $20^{\text {th }}$ Century logging. Although logging is now illegal, $21^{\text {st }}$ Century climate change constitutes a new - but so far unevaluated - threat to Araucaria's future survival. We use a robust ensemble modelling approach, using recently developed climate data, high-resolution topography and fine-scale vegetation maps, to predict the species' response to climate change and its implications for conservation on mesoand microclimate scales. We show that climate-only models predict the total disappearance of Araucaria's most suitable habitat by 2070 , but incorporating topographic effects allows potential highland microrefugia to be identified. The legacy of $20^{\text {th }}$ Century destruction is evident - more than a third of these likely holdouts have already lost their natural vegetation - and $21^{\text {st }}$ Century climate change will leave just $3.5 \%$ of remnant forest and $28.4 \%$ of highland grasslands suitable for Araucaria. Existing protected areas cover only $2.5 \%$ of the surviving microrefugia for this culturally important species, and none occur in any designated indigenous territory. Our results suggest that anthropogenic climate change is likely to commit Araucaria to a second consecutive century of significant losses, but targeted interventions could help ensure its survival in the wild.

\section{Keywords}

Araucaria angustifolia; microrefugia; conservation; climate change; species distribution modelling; Brazil

\section{Introduction}

Araucaria angustifolia (Bertol.) Kuntze (hereafter 'Araucaria') is a member of an ancient genus that dates back to the Jurassic period (Forest et al., 2018). Its iconic candelabra shape defines southern Brazil's Mixed Ombrophilous Forests (MOF) (Oliveira-Filho, Budke, Jarenkow, Eisenlohr, \& Neves, 2014), a unique formation of the Atlantic Forest biodiversity hotspot (L. D. S. Duarte, Bergamin, Marcilio-Silva, Seger, \& Marques, 2014; Myers, Mittermeier, Mittermeier, da Fonseca, \& Kent, 2000; Oliveira-Filho \& Fontes, 2000). Araucaria has also been a cultural keystone (Cristancho \& Vining, 2004; Garibaldi \& Turner, 2004) for millennia: it "could be considered the ritual object par excellence" for the indigenous southern Jê people (Fernandes \& Piovezana, 2015), and it is the most frequently-used plant species among Santa Catarina state's rural population (Justen, Müller, \&

This article is protected by copyright. All rights reserved. 
Toresan, 2012). Presently, Araucaria's chief economic value comes from its seeds (pinhão), which were a critical component in the southern Jê's diets before European arrival (Corteletti, Dickau, DeBlasis, \& Iriarte, 2015; Loponte, Carbonera, Corriale, \& Acosta, 2016) and remain a popular food source in Brazil today (Adan, Atchison, Reis, \& Peroni, 2016; Souza, Uarte de Matos, Forgiarini, \& Martinez, 2010; Zechini et al., 2018) - 9,293 tonnes, worth more than US\$5.5 million, were harvested in 2017 (IBGE, 2018). A National Pinhão Festival has been held in Santa Catarina for 30 years, and Araucaria is celebrated on Paraná state's coat of arms. But despite its long-standing cultural and economic value, $20^{\text {th }}$ Century deforestation left Araucaria Critically Endangered (Thomas, 2013).

Between 1910 and 1970, immigration from Europe, technological advances and Brazil's growing economy sparked a logging boom which destroyed $97 \%$ of Araucaria's habitat in just three generations, bringing the species to the brink of extinction (Carvalho \& Nodari, 2010; Nodari, 2016; Thomas, 2013). MOF's remaining fragments now cover only $12.6 \%$ of the biogeographic region once dominated by the forest (figure 1) (Ribeiro, Metzger, Martensen, Ponzoni, \& Hirota, 2009). This precarious present situation, combined with its long evolutionary history, makes Araucaria angustifolia the third most evolutionarily distinct and globally endangered (EDGE) of the planet's 1,090 gymnosperm species (Forest et al., 2018). And despite its legal protections, it is now at risk from $21^{\text {st }}$ Century climate change. MOF occupies the Atlantic Forest's coldest and highest-altitude extremes (Neves et al., 2017), requiring high year-round rainfall, temperate summers and cold minimum temperatures (average annual temperature $12-20^{\circ} \mathrm{C}$, with frequent winter frosts) (Alvares, Stape, Sentelhas, De Moraes Gonçalves, \& Sparovek, 2013; Hueck, 1953; Oliveira-Filho et al., 2014; Sevegnani, Uhlmann, Gasper, Meyer, \& Vibrans, 2016) - conditions likely to become rarer in the near future (Beck et al., 2018; Chou et al., 2014). Brazil is already experiencing anthropogenic warming of up to $1^{\circ} \mathrm{C}$ per decade, with rainfall regimes in the south disrupted as spring and autumn precipitation increases and winter rainfall declines (de Barros Soares, Lee, Loikith, Barkhordarian, \& Mechoso, 2017). Continued warming and further changes to the quantity and seasonality of precipitation are predicted over coming decades (Chou et al., 2014), though their impacts on Araucaria's remaining populations have not yet been tested. Indeed, no species in the genus Araucaria and none of the 14 highest ranked EDGE gymnosperm species - many of them with similar climatic requirements and recent population histories to $A$. angustifolia - have had their spatial responses to $21^{\text {st }}$ Century climate change examined.

There is a growing recognition, however, that modelling species' responses to changes at the macroclimatic scale (1-100km) may fail to account for how individual organisms experience locallevel climate (Ackerly et al., 2010; Ashcroft, 2010; Dobrowski, 2011; Hannah et al., 2014; Keppel et

This article is protected by copyright. All rights reserved. 
al., 2012; Lenoir, Hattab, \& Pierre, 2017). Fine-scale (1-100m) topography can modify both the speed and magnitude of environmental changes: shallow aquifers and lithologic contrasts can provide year-round moisture even when rainfall is reduced (McLaughlin et al., 2017); sheltered slopes have reduced rates of evaporation relative to those exposed to wind and direct sunlight (Ashcroft, Chisholm, \& French, 2008; Ashcroft \& Gollan, 2012); and convergent terrain permits the pooling of cold, moist air (Ashcroft \& Gollan, 2012; Daly, Conklin, \& Unsworth, 2010). When the "relict climates" (Dobrowski, 2011) in such locations enable a population to persist in a generally less suitable landscape they are referred to as microrefugia (Ashcroft, 2010; Hannah et al., 2014; Rull, 2009). As southern Brazil's temperatures rise and its rainfall regime continues to change, these relic 'cold spots' may become critical for Araucaria's continued survival. Whether these areas will act as potential 'stepping stones' to newly available habitats, or merely 'holdouts' into which its populations retreat with little hope of recovery, their identification and protection is an urgent conservation priority (Hannah et al., 2014; Keppel et al., 2012; Morelli et al., 2016).

Here we develop species distribution models for Araucaria angustifolia for the first time, using two different climatic datasets to project the species' responses to $21^{\text {st }}$ Century climate change, and incorporate ultra-fine scale topographic variables to investigate the role of cold spot microrefugia in moderating these. We then use high-resolution maps of remotely-sensed natural vegetation cover and the locations of existing protected areas to assess the conservation situation of these most resilient habitat patches.

\section{Methods}

To assess the role of microrefugia in promoting Araucaria's resilience to $21^{\text {st }}$ Century climate change, we first built ensemble species distribution models using established methodologies with climate data from Worldclim (Hijmans, Cameron, Parra, Jones, \& Jarvis, 2005) and CHELSA (Karger, Conrad, Böhner, Kawohl, Kreft, Soria-Auza, et al., 2017) ( $800 \mathrm{~m}$ resolution). We then generated a further ensemble model ('CHELSA+') using CHELSA climate data and three topographic variables (relative elevation, exposure of surfaces to prevailing wind and to direct insolation) inferred from a $30 \mathrm{~m}$ resolution elevation model. These models estimated Araucaria's ecological niche at present and in 2070 under two emissions scenarios - RCP4.5 (relatively optimistic) and RCP8.5 (pessimistic, business-as-usual). We considered areas where Araucaria's predicted probability of occurrence ( $p_{\text {occ}}$ ) was $\geq 75 \%$ in all three climate scenarios to be potential microrefugia. Using a map of remnant natural vegetation >3ha in area (Fundação SOS Mata Atlântica \& Instituto Nacional de Pesquisas Espaciais INPE, 2015), we identified potential microrefugia still within natural Campos (high-altitude

This article is protected by copyright. All rights reserved. 
grasslands) and forest fragments, as well as the larger vegetation patches these microrefugial populations may support. These locations were then cross-referenced with a database of Brazilian protected areas (UNEP-WCMC \& IUCN, 2018) to assess their conservation status.

\subsection{Occurrence, climate and topographic data}

We modelled Araucaria's potential distribution between $25-30^{\circ} \mathrm{S}$ and $54-48^{\circ} \mathrm{W}$. Presence and true absence records for Araucaria were taken from the Santa Catarina forest floristic inventory (IFFSC), a state-wide, systematic survey of natural forests using $4,000 \mathrm{~m}^{2}$ sample plots spaced 5-10 km apart (Alexander Christian Vibrans, Sevegnani, Lingner, de Gasper, \& Sabbagh, 2010). Overall, 1,670 individual Araucaria trees $>10 \mathrm{~cm}$ diameter at breast height were identified in the survey, of which we used one presence record per plot.

Additional occurrences from Misiones province (Argentina), Paraná and Rio Grande do Sul were obtained from the Global Biodiversity Information Facility (GBIF, $10^{\text {th }}$ January 2018, https://doi.org/10.15468/dl.7b5jat). After cleaning coordinates from GBIF, this combined dataset yielded 106 presence records ( 83 from IFFSC plots, 23 from GBIF). Araucaria trees were not recorded in 334 IFFSC plots; these localities were treated as true absences, although Araucaria's absence from these plots may be influenced by dispersal limitations, biotic interactions or disturbance history as well as climatic conditions. A random $20 \%$ of the locality data was set aside for model evaluation, with the remainder used for building and cross-validating the models. A MannWhitney-Wilcoxon text showed no significant differences between these datasets in terms of latitude $(p=0.48)$, longitude $(p=0.82)$ or altitude $(p=0.17)$.

Climate data were downloaded from Worldclim v1.4 (Hijmans et al., 2005) and CHELSA (Karger, Conrad, Böhner, Kawohl, Kreft, Soria-Auza, R.W., Zimmermann, et al., 2017; Karger, Conrad, Böhner, Kawohl, Kreft, Soria-Auza, et al., 2017) at 30 arc-second resolution. We used climate change projections for 2070 (average of 2061-2080, RCP4.5 and 8.5 emissions scenarios) from three General Circulation Models (GCMs): CCSM4, CNRM-CM5, and NorESM1-M were chosen because they have been shown to perform well in Latin America (Hidalgo \& Alfaro, 2015; Lovino, Müller, Berbery, \& Müller, 2018; Yin, Fu, Shevliakova, \& Dickinson, 2013) and were available for both Worldclim and CHELSA at the desired resolution. Best practice in SDM construction advocates restricting inputs to biologically relevant climate factors rather than using the full set of bioclimatic variables (Fourcade, Besnard, \& Secondi, 2017). We selected six, based on the subset of all variables which yielded the lowest Bayesian Information Criterion (BIC): isothermality (bio3), minimum temperature of the coldest month (bio6), mean temperature of the

This article is protected by copyright. All rights reserved. 
coldest month (bio11), annual precipitation (bio12), precipitation seasonality (bio15) and precipitation of the driest quarter (bio17). Multidimensional scaling showed these variables were not closely correlated (for correlation statistics, see figure S1), and they appear to be biologically relevant as Araucaria and MOF are associated with a constantly moist climate with no dry season, and constantly cool conditions with low minimum temperatures (Alvares et al., 2013; Hueck, 1953; Neves et al., 2017; Oliveira-Filho et al., 2014).

Topographic variables (exposure to solar irradiation, exposure to prevailing winds, relative elevation) were derived from the $30 \mathrm{~m}$-resolution ASTER global digital elevation model, a product of METI and NASA, downloaded from https://earthexplorer.usgs.gov. These variables were chosen as MOF at high elevations has been observed to prefer sheltered valley slopes and river banks (Hueck, 1953; Robinson et al., 2018), and because these areas are likely to represent colder and moister microclimates (Ashcroft et al., 2008; Ashcroft \& Gollan, 2012; Dobrowski, 2011; McLaughlin et al., 2017). The two exposure variables were calculated according to the methods in (Ashcroft et al., 2008) using azimuths of $315^{\circ}$ (i.e. north-west) for solar irradiation (McCune, 2007; McCune \& Keon, 2002) and $30^{\circ}, 60^{\circ}$ and $90^{\circ}$, subsequently averaged, for the region's prevailing winds (Camargo do Amarante, Brower, Zack, \& Leite de Sá, 2001). A point's relative elevation has been shown to effectively predict the level of cold air pooling it experiences (Ashcroft \& Gollan, 2012); we followed Ashcroft and Gollan (2012) by calculating this as the difference between a pixel's elevation and the minimum elevation within a $500 \mathrm{~m}$ radius. Although these variables are themselves static (i.e. will not change over the time scales studied here), they interact with changeable climate variables and so were included as explanatory variables in our CHELSA+ model (following Stanton, Pearson, Horning, Ersts, \& Reşit Akçakaya, 2012).

\subsection{Model construction}

Species distribution models (SDMs) were constructed using the biomod2 package (Thuiller, Georges, Engler, \& Breiner, 2016) in R v.3.4.2 (R Core Team, 2017). We created ensemble models by averaging high-performing model runs from seven (CHELSA+) or eight (Worldclim, CHELSA) algorithms: generalised linear models (GLMs), generalised additive models (GAMs), artificial neural networks (ANNs), maximum entropy (Maxent (Phillips, Anderson, Dudík, Schapire, \& Blair, 2017)), generalised boosting models (GBMs), random forests (RFs), classification tree analysis (CTA), and multiple adaptive regression splines (MARS). For computational reasons, Maxent was not run for CHELSA+. Each algorithm was run ten times, and assessed using the area under the receiver operating curve (AUC) and true skill statistic (TSS) metrics (Allouche, Tsoar, \& Kadmon, 2006). TSS

This article is protected by copyright. All rights reserved. 
varies from -1 to +1 , with 0 signifying a model no different to random; AUC varies from 0 to 1 , with a random classifier expected to score 0.5 . Projections from model runs with TSS $\geq 0.65$ and AUC $\geq 0.9$ for both cross-validation and evaluation were averaged to produce 'hibar' ensembles; 'lobar' ensembles averaged model runs with TSS scores $\geq 0.6$ and AUC $\geq 0.85$ (table 1 ). These ensemble models were then projected into scenarios for 2070 (relatively optimistic RCP4.5 and pessimistic, business-as-usual RCP8.5) using climate data from each GCM for Worldclim and CHELSA, with an average prediction subsequently taken. Due to the computational demands of CHELSA+, only the CCSM4 scenarios were run - this GCM was chosen as it makes the most accurate predictions of temperature and precipitation in this region (Lovino et al., 2018).

For subsequent analysis we categorised the continuous model output (probability of occurrence, $p_{\text {occ }}$ ) into four equal classes, with divisions at $25 \%, 50 \%$ and $75 \%$. Because we can be most confident of Araucaria's presence in areas with $p_{\text {occ }} \geq 75 \%$, we consider locations which fall within it in all three modelled scenarios (present, RCP4.5 and RCP8.5) to be potential microrefugia. We also consider areas which have $p_{\text {occ }}$ of $\geq 50 \%$ in all three scenarios, but which do not qualify as potential microrefugia, to have moderate climatic resilience.

\subsection{Vegetation remnants and conservation areas}

To analyse the effects of past habitat loss, we used the 2013-2014 SOS Mata Atlântica atlas of remnant natural vegetation (Fundação SOS Mata Atlântica \& Instituto Nacional de Pesquisas Espaciais - INPE, 2015). This identified areas of natural vegetation larger than three hectares using satellite imagery at 1:50,000 scale (approximately $25 \mathrm{~m}$ resolution) in the Brazilian states of Paraná, Santa Catarina and Rio Grande do Sul, which constitute $>98 \%$ of our study area; small parts of São Paulo state and Argentina's Misiones province are excluded. We used this dataset to locate areas of conservation priority, by identifying which microrefugia and moderately resilient areas occur within this remnant vegetation, and which have lost their natural vegetation. We also identified areas of remnant vegetation contiguous with significant microrefugia. We defined these as continuous areas of forest or natural non-forest (almost all of which is Campos in our study region) which either contained $\geq 100$ microrefugial cells $\left(0.09 \mathrm{~km}^{2}\right)$ or had microrefugial cells covering $\geq 5 \%$ of their area, i.e. vegetation patches which contain relatively large areas of microrefugia, or which are small but largely resilient.

This article is protected by copyright. All rights reserved. 
To assess the present conservation situation of these potential microrefugia, we compared the sites of microrefugia and resilient patches identified above with the locations of all Brazilian protected areas and designated Terras Indigenas within our study area (figure 1), downloaded from the World Database on Protected Areas (UNEP-WCMC \& IUCN, 2018).

\section{Results}

Between 3.9 and 4.5 times as many model runs, from a wider range of algorithms, met our quality thresholds when using CHELSA compared to Worldclim (table 1). Since the 'hibar' Worlclim ensemble model contained only two model runs from a single algorithm, we chose to analyse the 'Iobar' Worldclim ensemble; 'hibar' ensembles were used for CHELSA and CHELSA+.

Araucaria's predicted present distribution in all three models (figure 2 ) is similar to MOF's potential distribution (figure 1) with high-altitude grassland areas also predicted to be suitable, aligning with palaeoecological evidence that the forests have been expanding over Campos through the last 4,000 years (Behling, Pillar, Orlóci, \& Bauermann, 2004; Jeske-Pieruschka, Pillar, de Oliveira, \& Behling, 2013; Scherer \& Lorscheitter, 2014; Silva \& Anand, 2011). The future projections based on Worldclim and CHELSA data differ markedly, however (figure 2, table S1). Although both predict a total loss of the most climatically suitable habitat by 2070 (99.9\%-100.0\% losses of habitat with $p_{\text {occ }} \geq 75 \%$ under CHELSA, 100.0\% under Worldclim), Worldclim also predicts significant losses in all but the least suitable ( $p_{\text {occ }} 0-25 \%$ ) habitat, which rises to make up $87.2 \%-91.0 \%$ of the study area. The few areas of moderate suitability ( $p_{\text {occ }} 50-75 \%$ ) are found in the southeast and centre of the highland plateau, with some further marginal areas ( $p_{\text {occ }} 25-50 \%$ ) in the far northeast of our study area. CHELSA, by contrast, predicts $98.5 \%-100.0 \%$ losses in the least suitable habitat, with marginal and intermediate habitat rising to make up $99.5 \%-100.0 \%$ of the study area. Much of this increase is in presently unsuitable areas in the south-western part of the highlands, the southern edge of the study area where the plateau falls away, and the coastal strip east of the plateau's escarpment; Araucaria's present core areas become less suitable.

CHELSA climate-only models predict $99.9 \%-100.0 \%$ loss of presently highly suitable habitat ( $p_{\text {occ }}$ $275 \%$ ) in the future, but the incorporation of fine-scale topographic variables leads CHELSA+ to predict some persistence across the high elevation areas in the central and southeastern areas of the plateau, much of it along river valleys (table S1, figure 2). And although CHELSA+ still projects $85.3 \%-93.2 \%$ losses of this habitat class (table S1), it does identify $4,948 \mathrm{~km}^{2}$ of potential microrefugia, as well as $24 \%$ more moderately resilient habitat (defined as $p_{\text {occ }} \geq 50 \%$ in all scenarios)

This article is protected by copyright. All rights reserved. 
than predicted by CHELSA alone (table 2). However, the impact of $20^{\text {th }}$ Century land use change can be seen, with $37.4 \%$ of potential microrefugia having lost their natural vegetation cover, rising to $82.4 \%$ of all moderately resilient habitat (table 2 , figure 3 ). These losses are particularly acute in forest remnants, which make up only $6.7 \%\left(333 \mathrm{~km}^{2}\right)$ of all Araucaria's potential microrefugia. This represents a climate-caused reduction of $96.5 \%$ from the $9,577 \mathrm{~km}^{2}$ of forest where Araucaria is presently $\geq 75 \%$ likely to occur.

The majority of the most resilient habitat is predicted to occur in Campos. These naturally nonforested areas make up more than half of all potential microrefugia and $89.3 \%$ of those which have retained their natural vegetation, although CHELSA+ predicts that $71.6 \%$ of the presently most suitable Campos will be lost in future. The analysis of patches containing significant microrefugial areas shows that 679 patches of Campos, totalling $7,089 \mathrm{~km}^{2}$ and covering on average $10.4 \mathrm{~km}^{2}$ each, have $\geq 5 \%$ of their area covered by potential microrefugia or contain $\geq 100$ microrefugial cells. By contrast, the $4,801 \mathrm{~km}^{2}$ of forest patches which meet these criteria are found in 1,967 separate forest fragments, averaging only $2.4 \mathrm{~km}^{2}$ per patch - a number which falls to $1.4 \mathrm{~km}^{2}$ when excluding an outlier patch covering $41 \%$ of the total area (despite containing only $6.7 \mathrm{~km}^{2}$ of microrefugia).

The great majority of microrefugia, and the habitat patches they reside within, are located outside existing conservation infrastructure (Figure 4). Of all Araucaria's microrefugia which still have natural vegetation cover, only $2.5 \%$ are in any protected area, with a higher proportion of microrefugia in remnant forest represented $\left(5.6 \%, 18.6 \mathrm{~km}^{2}\right)$ than those in Campos $\left(2.2 \%, 59.5 \mathrm{~km}^{2}\right)$. Two national parks (Aparados da Serra and São Joaquim) contain $83.3 \%$ of all the protected Campos microrefugia and the two largest areas of highly resilient forest $\left(6.7 \mathrm{~km}^{2}\right.$ and $4.0 \mathrm{~km}^{2}$, respectively). Nine other protected areas average $0.9 \mathrm{~km}^{2}$ of forest microrefugia each, and four of these hold the remaining $9.9 \mathrm{~km}^{2}$ of protected Campos microrefugia. And although natural vegetation patches holding significant microrefugial components are found in fifteen protected areas (with six more, far from microrefugial cells, in the east of the outlier forest fragment discussed above), half (50.8\%) of the total protected area is concentrated in São Joaquim National Park, which holds $162.4 \mathrm{~km}^{2}$ of forest patches containing microrefugia and $148.3 \mathrm{~km}^{2}$ of similar patches in Campos.

This article is protected by copyright. All rights reserved. 


\section{Discussion}

Our results clearly show the disruptive effect that $21^{\text {st }}$ Century climate change will have on Araucaria's already precarious position in southern Brazil, with both Worldclim and CHELSA climateonly models showing that, by 2070 and under both emissions scenarios, there will be nowhere in the region where Araucaria's probability of occurrence is $\geq 75 \%$. The differences between the projections of the Worldclim and CHELSA models are primarily due to differences between the datasets' predictions of future climates (figure S3). Worldclim forecasts several degrees of warming at the coldest times of year, making the environment generally less favourable for Araucaria, whereas CHELSA's predictions paint a more complicated picture in which higher isothermality with colder minima than at present favour Araucaria, offset by increasingly seasonal precipitation and drier driest seasons (figure S4). The greater increases in isothermality and dry quarter precipitation in CHELSA's RCP8.5 scenario, and its lower values for coldest temperatures and precipitation seasonality, explain Araucaria's slightly more favourable response under this more pessimistic emissions scenario. Worldclim's projections are based on interpolated weather station records (Hijmans et al., 2005), whereas CHELSA's are based on an orographically-informed statistical downscaling of the ERA-Interim climate reanalysis (Karger, Conrad, Böhner, Kawohl, Kreft, SoriaAuza, et al., 2017). Worldclim is known to perform relatively poorly, particularly when predicting precipitation, in data-sparse and topographically complex environments, where CHELSA's predictions are more accurate (Deblauwe et al., 2016; Hijmans et al., 2005; Karger, Conrad, Böhner, Kawohl, Kreft, Soria-Auza, et al., 2017; Soria-Auza et al., 2010).

Exactly how Araucaria responds to the predicted climatic changes will depend largely on how it is affected by suboptimal conditions, which are predicted to prevail by the models built on the more accurate CHELSA data. The resilience of Araucaria populations will depend on how these conditions affect recruitment (Araucaria trees are most vulnerable as seedlings (Giovani F Paludo, Lauterjung, Dos Reis, \& Mantovani, 2016; Giovani Festa Paludo, Mantovani, \& Reis, 2011), when their preferred climatic conditions may differ from those around the adults used to build our models) and adult mortality (presently, portions of populations can survive for centuries even when suffering regeneration failure (Giovani F Paludo et al., 2016)). If Araucaria is relatively resilient to these changes its range could theoretically expand, although the intense fragmentation of the seasonally deciduous forests in the west of our study area (figure 1) severely limits dispersal in that direction, and Araucaria may be prevented from moving eastward by competitive exclusion from incumbent taxa in the dense coastal lowland forests (L. S. Duarte, Dillenburg, \& Rosa, 2002).

Given the uncertainties around Araucaria's responses to suboptimal conditions, the conservation of

This article is protected by copyright. All rights reserved. 
microrefugia - where Araucaria has and will retain a high probability of occurring - is essential. That more than a third of potential microrefugial area has already suffered habitat loss highlights the importance of safeguarding remaining natural vegetation from further damage. It also suggests that promoting Araucaria's conservation outside areas of natural vegetation could be a complementary goal. This could take the form of reforestation in resilient areas (though whether other key MOF species would have similar preferred areas in the future is uncertain), or the good stewardship of semi-natural landscapes in these areas. Some such areas, traditionally managed for cattle or nontimber forest products, can conserve Araucaria's genetic diversity as effectively as protected areas while also providing economic incentives to retain the trees (Medina-Macedo et al., 2016; Reis et al., 2018; Zechini et al., 2018), so their inclusion in conservation planning is likely to improve Araucaria's climate resilience. However, the legal restrictions on felling mature Araucaria trees (and on land use changes in areas containing them) have led some land owners to actively prevent Araucaria's natural regeneration by removing its seedlings from their properties (Adan et al., 2016; Mello \& Peroni, 2015; Alexander C Vibrans et al., 2011); addressing this issue is critical in order for private lands to contribute effectively to the species' long-term conservation.

Our results show that most of Araucaria's microrefugia still found in natural vegetation are in Campos (highland areas classed as 'naturally non-forested' in the SOS Mata Atlântica data). These areas are not only predicted to be more climatically stable than forest areas but are also more intact, with microrefugia spread out over fewer, larger patches. Part of the fragmentation of resilient forest is due to $20^{\text {th }}$ Century habitat loss, but it is also reflective of the natural vegetation mosaic at the high elevations where potential microrefugia are found. Here, where MOF and Campos meet, trees are restricted to small patches and gallery forests embedded within the more extensive grassland matrix; many of the areas classified as natural non-forest in our study also contain additional woodland islands too small to be classified as forest in the SOS Mata Atlântica vegetation map (i.e. <3ha; Fundação SOS Mata Atlântica \& Instituto Nacional de Pesquisas Espaciais - INPE, 2015). The conservation of Araucaria in this context raises potential conflicts of priorities. Campos have significant biodiversity and conservation importance in their own right (Iganci, Heiden, Miotto, \& Pennington, 2011; Overbeck et al., 2007), so human intervention to accelerate the slow natural expansion of MOF patches over the surrounding grasslands (Müller, Overbeck, Blanco, de Oliveira, \& Pillar, 2012; Silva \& Anand, 2011), as the southern Jê are hypothesised to have done around 1,000 years ago (Bitencourt \& Krauspenhar, 2006; Robinson et al., 2018), may not be desirable. Ecotones between the grassland matrix and embedded MOF areas are maintained by anthropogenic fire and cattle grazing, to which forest species like Araucaria are more susceptible (Jeske-Pieruschka, Fidelis, Bergamin, Vélez, \& Behling, 2010; Müller et al., 2012; Oliveira \& Pillar, 2005), so a delicate

This article is protected by copyright. All rights reserved. 
management balance is needed to conserve the Campos habitat itself, the MOF islands and gallery forests within it, and the dynamics between these ecosystems.

However, Campos are among Brazil's most underprotected ecosystems (Overbeck et al., 2007), and an accordingly small proportion (2.5\%) of all Araucaria's microrefugia are in any protected area. None occur within existing Terras Indigenas, something that may have significant cultural impacts on the groups to whom Araucaria has long been important (cf. Bond, Anderson, Henare, \& Wehi, 2019). In response to this challenge, it is essential that existing protected areas are effectively managed and safeguarded, that Araucaria is promoted and conserved on private land outside protected areas, and that new protections are considered for areas likely to play a major role in securing Araucaria's resilience to $21^{\text {st }}$ Century climate change.

Brazil's Araucaria is far from the only tree species threatened by historic deforestation and future climate change, and applying the multifaceted approach used in this study could improve the realism and effectiveness of distribution models used to guide their conservation. By employing sophisticated CHELSA data alongside Worldclim, we increase our confidence in the predictions of Araucaria's responses - a step which can be applied to other topographically complex regions with sparse climate data where the interpolated climate surfaces of Worldclim may be less appropriate (Deblauwe et al., 2016; Hijmans et al., 2005; Karger, Conrad, Böhner, Kawohl, Kreft, Soria-Auza, et al., 2017; Soria-Auza et al., 2010). Similarly, the inclusion of topographic variables in our species distribution models (cf. Stanton et al., 2012) allows potential microrefugia to be identified at high resolution without prior microclimatic research having taken place (cf. Ashcroft \& Gollan, 2012; Slavich, Warton, Ashcroft, Gollan, \& Ramp, 2014). Our use of remotely-sensed vegetation maps to analyse the interacting impacts of climate change and habitat loss on Araucaria is a further step which can be applied in the study of other species threatened by these two key drivers of global biodiversity decline.

Fine-scale species distribution models are known to predict patchier distributions and improved persistence compared to those conducted at coarser resolutions (Meineri \& Hylander, 2017; Storlie, Phillips, Vanderwal, \& Williams, 2013), an effect also found in this study. The concept of microrefugia is one with origins in palaeoecology (Bemmels, Knowles, \& Dick, 2019; Dobrowski, 2011; Petit, Hu, \& Dick, 2008; Rull, 2009) but which is increasingly recognised as highly relevant for conservation ecology (Ashcroft, 2010; Hannah et al., 2014; McLaughlin \& Zavaleta, 2012; Suggitt et al., 2018). Our finding that some areas among the grasslands on southern Brazil's highlands are likely to shelter microrefugia for Araucaria echoes the species' past ecology: previous relatively rapid expansions of forest on the plateau are thought to have been facilitated by the expansion and persistence of

This article is protected by copyright. All rights reserved. 
gallery forests through the late Pleistocene and Holocene (Behling et al., 2004; Costa et al., 2017). Whether the patches of microrefugial vegetation we have identified in this study will similarly persist and act as sources of future forest expansion is far from certain, however, as our findings show that significant portions of this resilient habitat have either already been lost or currently lie outside formal protected areas. And, with the next century's climate likely to be highly novel compared to the present and recent past (Fischer et al., 2018; Fitzpatrick et al., 2018), an improved understanding of Araucaria's spatial dynamics throughout the Quaternary may be essential for truly long-term conservation planning.

Araucaria's long evolutionary history, its past and present cultural and economic significance, and its Critically Endangered status combine to make such planning an urgent task. Deforestation between 1870 and 1970 left less than $3 \%$ of Araucaria's former forest habitat standing by the late $20^{\text {th }}$ Century (Thomas, 2013). Here we have shown that climate change is likely to repeat these losses within this century: of the $9,577 \mathrm{~km}^{2}$ of forest fragments in our study region where Araucaria currently has $\geq 75 \%$ probability of occurring, only $3.5 \%$ will remain similarly suitable by 2070 . However, by highlighting the areas whose climatic and topographic conditions give Araucaria the best chance of persisting, we hope to encourage the critical conservation measures needed for this iconic tree to see another century on the highlands.

\section{Acknowledgements}

We thank King Wong and Ryan Kennedy for organising access to the University of Reading Research Cloud for this study. The IFFSC is funded by the Fundação de Amparo à Pesquisa e Inovação do Estado de Santa Catarina (FAPESC). OJW is supported by a Graduate Teaching Assistant PhD studentship from the University of Reading, and thanks M. Jane Bunting for logistical support while undertaking this research. ACV is supported by Conselho Nacional de Desenvolvimento Científico e Tecnológico (CNPq) research grant 312075/2013-8. We thank the two anonymous reviewers whose constructive comments strengthened this manuscript.

\section{Author contributions}

OJW, RJW and FEM conceived the study; OJW and RJW designed the analysis; DVL and ACV provided IFFSC locality data; OJW built the ensemble models and analysed the results; OJW, RJW and FEM drafted the manuscript, which all authors revised before submission.

This article is protected by copyright. All rights reserved. 


\section{References}

Ackerly, D. D., Loarie, S. R., Cornwell, W. K., Weiss, S. B., Hamilton, H., Branciforte, R., \& Kraft, N. J. B. (2010). The geography of climate change: Implications for conservation biogeography. Diversity and Distributions, 16(3), 476-487. https://doi.org/10.1111/j.1472-4642.2010.00654.x

Adan, N., Atchison, J., Reis, M. S., \& Peroni, N. (2016). Local Knowledge, Use and Management of Ethnovarieties of Araucaria angustifolia (Bert.) Ktze. in the Plateau of Santa Catarina, Brazil. Economic Botany, 70(4), 353-364. https://doi.org/10.1007/s12231-016-9361-z

Allouche, O., Tsoar, A., \& Kadmon, R. (2006). Assessing the accuracy of species distribution models: Prevalence, kappa and the true skill statistic (TSS). Journal of Applied Ecology, 43(6), 12231232. https://doi.org/10.1111/j.1365-2664.2006.01214.x

Alvares, C. A., Stape, J. L., Sentelhas, P. C., De Moraes Gonçalves, J. L., \& Sparovek, G. (2013). Köppen's climate classification map for Brazil. Meteorologische Zeitschrift, 22(6), 711-728. https://doi.org/10.1127/0941-2948/2013/0507

Ashcroft, M. B. (2010). Identifying refugia from climate change. Journal of Biogeography, 37(8), 1407-1413. https://doi.org/10.1111/j.1365-2699.2010.02300.x

Ashcroft, M. B., Chisholm, L. A., \& French, K. O. (2008). The effect of exposure on landscape scale soil surface temperatures and species distribution models. Landscape Ecology, 23(2), 211-225. https://doi.org/10.1007/s10980-007-9181-8

Ashcroft, M. B., \& Gollan, J. R. (2012). Fine-resolution (25 m) topoclimatic grids of near-surface (5 $\mathrm{cm})$ extreme temperatures and humidities across various habitats in a large $(200 \times 300 \mathrm{~km})$ and diverse region. International Journal of Climatology, 32(14), 2134-2148. https://doi.org/10.1002/joc.2428

Beck, H. E., Zimmermann, N. E., McVicar, T. R., Vergopolan, N., Berg, A., \& Wood, E. F. (2018). Present and future Köppen-Geiger climate classification maps at 1-km resolution. Scientific Data, 5, 180214. https://doi.org/10.1038/sdata.2018.214

Behling, H., Pillar, V. D., Orlóci, L., \& Bauermann, S. G. (2004). Late Quaternary Araucaria forest, grassland (Campos), fire and climate dynamics, studied by high-resolution pollen, charcoal and multivariate analysis of the Cambará do Sul core in southern Brazil. Palaeogeography, Palaeoclimatology, Palaeoecology, 203(3-4), 277-297. https://doi.org/10.1016/S00310182(03)00687-4

This article is protected by copyright. All rights reserved. 
Bemmels, J. B., Knowles, L. L., \& Dick, C. W. (2019). Genomic evidence of survival near ice sheet margins for some, but not all, North American trees. Proceedings of the National Academy of Sciences, 116(17), 8431-8436. https://doi.org/10.1073/pnas.1901656116

Bitencourt, A. L. V., \& Krauspenhar, P. M. (2006). Possible prehistoric anthropogenic effect on Araucaria angustifolia (Bert.) O. Kuntze expansion during the late Holocene. Revista Brasileira de Paleontologia, 9(1), 109-116.

Bond, M. O., Anderson, B. J., Henare, T. H. A., \& Wehi, P. M. (2019). Effects of climatically shifting species distributions on biocultural relationships. People and Nature, 1(1), 87-102. https://doi.org/10.1002/pan3.15

Camargo do Amarante, O. A., Brower, M., Zack, J., \& Leite de Sá, A. (2001). Atlas do Potencial Eólico Brasileiro. Brasília. Retrieved from http://www.cresesb.cepel.br/publicacoes/download/atlas_eolico/Atlas do Potencial Eolico Brasileiro.pdf

Carvalho, M. M. X. de, \& Nodari, E. S. (2010). As fases da exploração madeireira na floresta com Araucária e os progressivos avanços da indústria madeireira sobre as florestas primárias ( 18701970 ). In Simpósio Internacional de História Ambiental e Migrações (pp. 707-726). Florianópolis: UFSC. Retrieved from www.labimha.ufsc.br

Chou, S. C., Lyra, A., Mourão, C., Dereczynski, C., Pilotto, I., Gomes, J., ... Marengo, J. (2014). Assessment of Climate Change over South America under RCP 4.5 and 8.5 Downscaling Scenarios. American Journal of Climate Change, 03(05), 512-527. https://doi.org/10.4236/ajcc.2014.35043

Corteletti, R., Dickau, R., DeBlasis, P., \& Iriarte, J. (2015). Revisiting the economy and mobility of southern proto-Jê (Taquara-Itararé) groups in the southern Brazilian highlands: Starch grain and phytoliths analyses from the Bonin site, Urubici, Brazil. Journal of Archaeological Science, 58, 46-61. https://doi.org/10.1016/j.jas.2015.03.017

Costa, G. C., Hampe, A., Ledru, M. P., Martinez, P. A., Mazzochini, G. G., Shepard, D. B., ... Carnaval, A. C. (2017). Biome stability in South America over the last 30 kyr: Inferences from long-term vegetation dynamics and habitat modelling. Global Ecology and Biogeography, (August 2017), 285-297. https://doi.org/10.1111/geb.12694

Cristancho, S., \& Vining, J. (2004). Culturally defined keystone species. Human Ecology Review, 11(2), 153-164.

This article is protected by copyright. All rights reserved. 
Daly, C., Conklin, D. R., \& Unsworth, M. H. (2010). Local atmospheric decoupling in complex topography alters climate change impacts. International Journal of Climatology, 30(12), 18571864. https://doi.org/10.1002/joc.2007

de Barros Soares, D., Lee, H., Loikith, P. C., Barkhordarian, A., \& Mechoso, C. R. (2017). Can significant trends be detected in surface air temperature and precipitation over South America in recent decades? International Journal of Climatology, 37(3), 1483-1493. https://doi.org/10.1002/joc.4792

Deblauwe, V., Droissart, V., Bose, R., Sonké, B., Blach-Overgaard, A., Svenning, J. C., ... Couvreur, T. L. P. (2016). Remotely sensed temperature and precipitation data improve species distribution modelling in the tropics. Global Ecology and Biogeography, 25(4), 443-454. https://doi.org/10.1111/geb.12426

Dobrowski, S. Z. (2011). A climatic basis for microrefugia: The influence of terrain on climate. Global Change Biology, 17(2), 1022-1035. https://doi.org/10.1111/j.1365-2486.2010.02263.x

Duarte, L. D. S., Bergamin, R. S., Marcilio-Silva, V., Seger, G. D. D. S., \& Marques, M. C. M. (2014). Phylobetadiversity among forest types in the Brazilian Atlantic Forest complex. PLOS ONE, 9(8). https://doi.org/10.1371/journal.pone.0105043

Duarte, L. S., Dillenburg, L. R., \& Rosa, L. M. G. (2002). Assessing the role of light availability in the regeneration of Araucaria angustifolia (Araucariaceae). Australian Journal of Botany, 50(6), 741-751. https://doi.org/10.1071/BT02027

Fernandes, R. C., \& Piovezana, L. (2015). The Kaingang perspectives on land and environmental rights in the south of Brazil. Ambiente \& Sociedade, 18(2), 111-128. https://doi.org/10.1590/18094422ASOCEx07V1822015en

Fischer, H., Meissner, K. J., Mix, A. C., Abram, N. J., Austermann, J., Brovkin, V., ... Zhou, L. (2018). Palaeoclimate constraints on the impact of $2{ }^{\circ} \mathrm{C}$ anthropogenic warming and beyond. Nature Geoscience, 11(7), 474-485. https://doi.org/10.1038/s41561-018-0146-0

Fitzpatrick, M. C., Blois, J. L., Williams, J. W., Nieto-Lugilde, D., Maguire, K. C., \& Lorenz, D. J. (2018). How will climate novelty influence ecological forecasts? Using the Quaternary to assess future reliability. Global Change Biology, 24(8), 3575-3586. https://doi.org/10.1111/gcb.14138

Forest, F., Moat, J., Baloch, E., Brummitt, N. A., Bachman, S. P., Ickert-Bond, S., ... Buerki, S. (2018). Gymnosperms on the EDGE. Scientific Reports, 8(1), 6053. https://doi.org/10.1038/s41598018-24365-4

This article is protected by copyright. All rights reserved. 
Fourcade, Y., Besnard, A. G., \& Secondi, J. (2017). Paintings predict the distribution of species, or the challenge of selecting environmental predictors and evaluation statistics. Global Ecology and Biogeography, (October). https://doi.org/10.1111/geb.12684

Fundação SOS Mata Atlântica, \& Instituto Nacional de Pesquisas Espaciais - INPE. (2015). Atlas dos Remanescentes Florestais da Mata Atlântica Período 2013-2014: Relatório Técnico. São Paulo.

Garibaldi, A., \& Turner, N. (2004). Cultural keystone species: Implications for ecological conservation and restoration. Ecology and Society, 9(3), 1. Retrieved from http://www.ecologyandsociety.org/vol9/iss3/art1

Hannah, L., Flint, L., Syphard, A. D., Moritz, M. A., Buckley, L. B., \& McCullough, I. M. (2014). Finegrain modeling of species' response to climate change: holdouts, stepping-stones, and microrefugia. Trends in Ecology \& Evolution, 29(7), 390-397. https://doi.org/10.1016/j.tree.2014.04.006

Hidalgo, H. G., \& Alfaro, E. J. (2015). Skill of CMIP5 climate models in reproducing 20th century basic climate features in Central America. International Journal of Climatology, 35(12), 3397-3421. https://doi.org/10.1002/joc.4216

Hijmans, R. J., Cameron, S. E., Parra, J. L., Jones, P. G., \& Jarvis, A. (2005). Very high resolution interpolated climate surfaces for global land areas. International Journal of Climatology, 25(15), 1965-1978. https://doi.org/10.1002/joc.1276

Hueck, K. (1953). Distribuição e habitat natural do Pinheiro do Paraná (Araucaria angustifolia). Boletim Da Faculdade de Filosofia, Ciências e Letras, Universidade de São Paulo., 10, 5-24. https://doi.org/10.11606/issn.2318-5988.v10i1p5-24

IBGE. (2004). Mapa de Vegetação do Brasil. Rio de Janeiro: Instituto Brasileiro de Geografia e Estatística.

IBGE. (2018). Produção da Extração Vegetal e Silvicultura 2017. Rio de Janeiro: Instituto Brasileiro de Geografia e Estatística. Retrieved from https://cidades.ibge.gov.br/brasil/pesquisa/16/12705

Iganci, J. R. V, Heiden, G., Miotto, S. T. S., \& Pennington, R. T. (2011). Campos de Cima da Serra: The Brazilian Subtropical Highland Grasslands show an unexpected level of plant endemism. Botanical Journal of the Linnean Society, 167(4), 378-393. https://doi.org/10.1111/j.10958339.2011.01182.x

Jeske-Pieruschka, V., Fidelis, A., Bergamin, R. S., Vélez, E., \& Behling, H. (2010). Araucaria forest dynamics in relation to fire frequency in southern Brazil based on fossil and modern pollen

This article is protected by copyright. All rights reserved. 
data. Review of Palaeobotany and Palynology, 160(1-2), 53-65. https://doi.org/10.1016/j.revpalbo.2010.01.005

Jeske-Pieruschka, V., Pillar, V. D., de Oliveira, M. A. T., \& Behling, H. (2013). New insights into vegetation, climate and fire history of southern Brazil revealed by a 40,000 year environmental record from the State Park Serra do Tabuleiro. Vegetation History and Archaeobotany, 22(4), 299-314. https://doi.org/10.1007/s00334-012-0382-y

Justen, J. K. G., Müller, J. J. V., \& Toresan, L. (2012). Levantamento Socioambiental. In A.C. Vibrans, L. Sevegnani, A. L. de Gasper, \& D. V. Lingner (Eds.), Inventário Florístico Florestal de Santa Catarina Volume I - Diversidade e conservação dos remanescentes florestais (pp. 243-259). Blumenau: Edifurb.

Karger, D. N., Conrad, O., Böhner, J., Kawohl, T., Kreft, H., Soria-Auza, R.W., Zimmermann, N. E., ... Kessler, M. (2017). Data from: Climatologies at high resolution for the earth's land surface areas. Dryad Digital Repository. https://doi.org/https://doi.org/10.5061/dryad.kd1d4

Karger, D. N., Conrad, O., Böhner, J., Kawohl, T., Kreft, H., Soria-Auza, R. W., ... Kessler, M. (2017). Climatologies at high resolution for the earth's land surface areas. Scientific Data, 4, 170122. https://doi.org/10.1038/sdata.2017.122

Keppel, G., Van Niel, K. P., Wardell-Johnson, G. W., Yates, C. J., Byrne, M., Mucina, L., ... Franklin, S. E. (2012). Refugia: identifying and understanding safe havens for biodiversity under climate change. Global Ecology and Biogeography, 21(4), 393-404. https://doi.org/10.1111/j.14668238.2011.00686.x

Lenoir, J., Hattab, T., \& Pierre, G. (2017). Climatic microrefugia under anthropogenic climate change: implications for species redistribution. Ecography, 40(2), 253-266. https://doi.org/10.1111/ecog.02788

Loponte, D., Carbonera, M., Corriale, M. J., \& Acosta, A. (2016). Horticulturists and oxygen ecozones in the tropical and subtropical forests of Southeast South America. Environmental Archaeology, 22(3), 1-21. https://doi.org/10.1080/14614103.2016.1211382

Lovino, M. A., Müller, O. V, Berbery, E. H., \& Müller, G. V. (2018). Evaluation of CMIP5 retrospective simulations of temperature and precipitation in northeastern Argentina. International Journal of Climatology, 38, e1158-e1175. https://doi.org/10.1002/joc.5441

McCune, B. (2007). Improved estimates of incident radiation and heat load using non-parametric regression against topographic variables. Journal of Vegetation Science, 18(2002), 751-754.

This article is protected by copyright. All rights reserved. 
https://doi.org/10.1658/1100-9233(2007)18\%5B751:IEOIRA\%5D2.0.CO;2

McCune, B., \& Keon, D. (2002). Equations for Potential Annual Direct Incident Radiation and Heat Load. Journal of Vegetation Science, 13(4), 603-606. Retrieved from http://www.jstor.org/stable/3236745

McLaughlin, B. C., Ackerly, D. D., Klos, P. Z., Natali, J., Dawson, T. E., \& Thompson, S. E. (2017). Hydrologic refugia, plants, and climate change. Global Change Biology, 23(8), 2941-2961. https://doi.org/10.1111/gcb.13629

McLaughlin, B. C., \& Zavaleta, E. S. (2012). Predicting species responses to climate change: demography and climate microrefugia in California valley oak (Quercus lobata). Global Change Biology, 18(7), 2301-2312. https://doi.org/10.1111/j.1365-2486.2011.02630.x

Medina-Macedo, L., de Lacerda, A. E. B., Sebbenn, A. M., Ribeiro, J. Z., Soccol, C. R., \& Bittencourt, J. V. M. (2016). Using genetic diversity and mating system parameters estimated from genetic markers to determine strategies for the conservation of Araucaria angustifolia (Bert.) O. Kuntze (Araucariaceae). Conservation Genetics, 17(2), 413-423. https://doi.org/10.1007/s10592-0150793-2

Meineri, E., \& Hylander, K. (2017). Fine-grain, large-domain climate models based on climate station and comprehensive topographic information improve microrefugia detection. Ecography, 40(8), 1003-1013. https://doi.org/10.1111/ecog.02494

Mello, A. J. M., \& Peroni, N. (2015). Cultural landscapes of the Araucaria Forests in the northern plateau of Santa Catarina, Brazil. Journal of Ethnobiology and Ethnomedicine, 11(1), 51. https://doi.org/10.1186/s13002-015-0039-x

Morelli, T. L., Daly, C., Dobrowski, S. Z., Dulen, D. M., Ebersole, J. L., Jackson, S. T., ... Beissinger, S. R. (2016). Managing Climate Change Refugia for Climate Adaptation. PLOS ONE, 11(8), e0159909. https://doi.org/10.1371/journal.pone.0159909

Müller, S. C., Overbeck, G. E., Blanco, C. C., de Oliveira, J. M., \& Pillar, V. D. (2012). South Brazilian Forest-Grassland Ecotones: Dynamics Affected by Climate, Disturbance, and Woody Species Traits. In R. W. Myster (Ed.), Ecotones Between Forest and Grassland (Vol. 9781461437, pp. 167-187). New York, NY: Springer New York. https://doi.org/10.1007/978-1-4614-3797-0_7

Myers, N., Mittermeier, R. A., Mittermeier, C. G., da Fonseca, G. A. B., \& Kent, J. (2000). Biodiversity hotspots for conservation priorities. Nature, 403(6772), 853-858. https://doi.org/10.1038/35002501

This article is protected by copyright. All rights reserved. 
Neves, D. M., Dexter, K. G., Pennington, R. T., Valente, A. S. M., Bueno, M. L., Eisenlohr, P. V., ... Oliveira-Filho, A. T. (2017). Dissecting a biodiversity hotspot: The importance of environmentally marginal habitats in the Atlantic Forest Domain of South America. Diversity and Distributions, 23(8), 898-909. https://doi.org/10.1111/ddi.12581

Nodari, E. S. (2016). Historia de la devastación del Bosque de Araucaria en el sur del Brasil. Areas: Revista Internacional de Ciencias Sociales, 35, 75-85. Retrieved from http://revistas.um.es/areas/article/view/279171

Oliveira-Filho, A. T., Budke, J. C., Jarenkow, J. A., Eisenlohr, P. V, \& Neves, D. R. M. (2014). Delving into the variations in tree species composition and richness across South American subtropical Atlantic and Pampean forests. Journal of Plant Ecology, 8(3), 242-260. https://doi.org/10.1093/jpe/rtt058

Oliveira-Filho, A. T., \& Fontes, M. A. L. (2000). Patterns of Floristic Differentiation among Atlantic Forests in Southeastern Brazil and the Influence of Climate. Biotropica, 32(2), 793-810. https://doi.org/10.1111/j.1744-7429.2000.tb00619.x

Oliveira, J. M., \& Pillar, V. de P. (2005). Vegetation dynamics on mosaics of Campos and Araucaria forest between 1974 and 1999 in Southern Brazil. Community Ecology, 5(2), 197-202. https://doi.org/10.1556/ComEc.5.2004.2.8

Overbeck, G. E., Müller, S. C., Fidelis, A., Pfadenhauer, J., Pillar, V. D., Blanco, C. C., ... Forneck, E. D. (2007). Brazil's neglected biome: The South Brazilian Campos. Perspectives in Plant Ecology, Evolution and Systematics, 9(2), 101-116. https://doi.org/10.1016/j.ppees.2007.07.005

Paludo, Giovani F, Lauterjung, M. B., Dos Reis, M. S., \& Mantovani, A. (2016). Inferring population trends of Araucaria angustifolia (Araucariaceae) using a transition matrix model in an old$\begin{array}{llll}\text { growth forest. } & \text { Southern }\end{array}$ https://doi.org/10.2989/20702620.2015.1136506

Paludo, Giovani Festa, Mantovani, A., \& Reis, M. S. Dos. (2011). Regeneração de uma população natural de Araucaria angustifolia (Araucariaceae). Revista Árvore, 35(5), 1107-1119. https://doi.org/10.1590/S0100-67622011000600017

Petit, R. J., Hu, F. S., \& Dick, C. W. (2008). Forests of the Past: A Window to Future Changes. Science, 320(5882), 1450-1452. https://doi.org/10.1126/science.1155457

Phillips, S. J., Anderson, R. P., Dudík, M., Schapire, R. E., \& Blair, M. E. (2017). Opening the black box: an open-source release of Maxent. Ecography, 40(7), 887-893. 
https://doi.org/10.1111/ecog.03049

R Core Team. (2017). R: a Language and Environment for Statistical Computing. Vienna, Austria: R Foundation for Statistical Computing. Retrieved from www.R-project.org

Reis, M. S., Montagna, T., Mattos, A. G., Filippon, S., Ladio, A. H., Marques, A. da C., ... Mantovani, A. (2018). Domesticated Landscapes in Araucaria Forests, Southern Brazil: A Multispecies Local Conservation-by-Use System. Frontiers in Ecology and Evolution, 6, 11. https://doi.org/10.3389/fevo.2018.00011

Ribeiro, M. C., Metzger, J. P., Martensen, A. C., Ponzoni, F. J., \& Hirota, M. M. (2009). The Brazilian Atlantic Forest: How much is left, and how is the remaining forest distributed? Implications for conservation. Biological Conservation, 142(6), 1141-1153. https://doi.org/10.1016/j.biocon.2009.02.021

Robinson, M., De Souza, J. G., Maezumi, S. Y., Cárdenas, M., Pessenda, L., Prufer, K., ... Iriarte, J. (2018). Uncoupling human and climate drivers of late Holocene vegetation change in southern Brazil. Scientific Reports, 8(1), 7800. https://doi.org/10.1038/s41598-018-24429-5

Rull, V. (2009). Microrefugia. Journal of Biogeography, 36(3), 481-484. https://doi.org/10.1111/j.1365-2699.2008.02023.x

Scherer, C., \& Lorscheitter, M. L. (2014). Vegetation dynamics in the southern Brazilian highlands during the last millennia and the role of bogs in Araucaria forest formation. Quaternary International, 325, 3-12. https://doi.org/10.1016/j.quaint.2014.01.010

Sevegnani, L., Uhlmann, A., Gasper, A. L. de, Meyer, L., \& Vibrans, A. C. (2016). Climate affects the structure of mixed rain forest in southern sector of Atlantic domain in Brazil. Acta Oecologica, 77, 109-117. https://doi.org/10.1016/j.actao.2016.10.002

Silva, L. C. R., \& Anand, M. (2011). Mechanisms of Araucaria (Atlantic) Forest Expansion into Southern Brazilian Grasslands. Ecosystems, 14(8), 1354-1371. https://doi.org/10.1007/s10021011-9486-y

Slavich, E., Warton, D. I., Ashcroft, M. B., Gollan, J. R., \& Ramp, D. (2014). Topoclimate versus macroclimate: How does climate mapping methodology affect species distribution models and climate change projections? Diversity and Distributions, 20(8), 952-963. https://doi.org/10.1111/ddi.12216

Soria-Auza, R. W., Kessler, M., Bach, K., Barajas-Barbosa, P. M., Lehnert, M., Herzog, S. K., \& Böhner, J. (2010). Impact of the quality of climate models for modelling species occurrences in

This article is protected by copyright. All rights reserved. 
countries with poor climatic documentation: a case study from Bolivia. Ecological Modelling, 221(8), 1221-1229. https://doi.org/10.1016/j.ecolmodel.2010.01.004

Souza, A. F., Uarte de Matos, D., Forgiarini, C., \& Martinez, J. (2010). Seed crop size variation in the dominant South American conifer Araucaria angustifolia. Acta Oecologica, 36(1), 126-134. https://doi.org/10.1016/j.actao.2009.11.001

Stanton, J. C., Pearson, R. G., Horning, N., Ersts, P., \& Reşit Akçakaya, H. (2012). Combining static and dynamic variables in species distribution models under climate change. Methods in Ecology and Evolution, 3(2), 349-357. https://doi.org/10.1111/j.2041-210X.2011.00157.x

Storlie, C. J., Phillips, B. L., Vanderwal, J. J., \& Williams, S. E. (2013). Improved spatial estimates of climate predict patchier species distributions. Diversity and Distributions, 19(9), 1106-1113. https://doi.org/10.1111/ddi.12068

Suggitt, A. J., Wilson, R. J., Isaac, N. J. B., Beale, C. M., Auffret, A. G., August, T., ... Maclean, I. M. D. (2018). Extinction risk from climate change is reduced by microclimatic buffering. Nature Climate Change, 8(8), 713-717. https://doi.org/10.1038/s41558-018-0231-9

Thomas, P. (2013). Araucaria angustifolia. https://doi.org/http://dx.doi.org/10.2305/IUCN.UK.20131.RLTS.T32975A2829141.en

Thuiller, W., Georges, D., Engler, R., \& Breiner, F. (2016). biomod2: Ensemble Platform for Species Distribution Modeling. Retrieved from https://cran.r-project.org/package=biomod2

UNEP-WCMC, \& IUCN. (2018). Protected Planet: The World Database on Protected Areas (WDPA). Retrieved June 1, 2018, from www.protectedplanet.net

Vibrans, Alexander C, Sevegnani, L., Uhlmann, A., Schorn, L. A., Sobral, M. G., de Gasper, A. L., ... Verdi, M. (2011). Structure of mixed ombrophyllous forests with Araucaria angustifolia (Araucariaceae) under external stress in Southern Brazil. Revista de Biologia Tropical, 59(3), 1371-1387. Retrieved from http://www.scielo.sa.cr/pdf/rbt/v59n3/a35v59n3.pdf

Vibrans, Alexander Christian, Sevegnani, L., Lingner, D. V., de Gasper, A. L., \& Sabbagh, S. (2010). Inventário florístico florestal de Santa Catarina (IFFSC): aspectos metodológicos e operacionais. Pesquisa Florestal Brasileira, 30(64), 291-302. https://doi.org/10.4336/2010.pfb.64.291

Yin, L., Fu, R., Shevliakova, E., \& Dickinson, R. E. (2013). How well can CMIP5 simulate precipitation and its controlling processes over tropical South America? Climate Dynamics, 41(11-12), 31273143. https://doi.org/10.1007/s00382-012-1582-y

This article is protected by copyright. All rights reserved. 
Zechini, A. A., Lauterjung, M. B., Candido-Ribeiro, R., Montagna, T., Bernardi, A. P., Hoeltgebaum, M. P., ... dos Reis, M. S. (2018). Genetic Conservation of Brazilian Pine (Araucaria angustifolia) Through Traditional Land Use. Economic Botany, 1-14. https://doi.org/10.1007/s12231-0189414-6

\section{Tables}

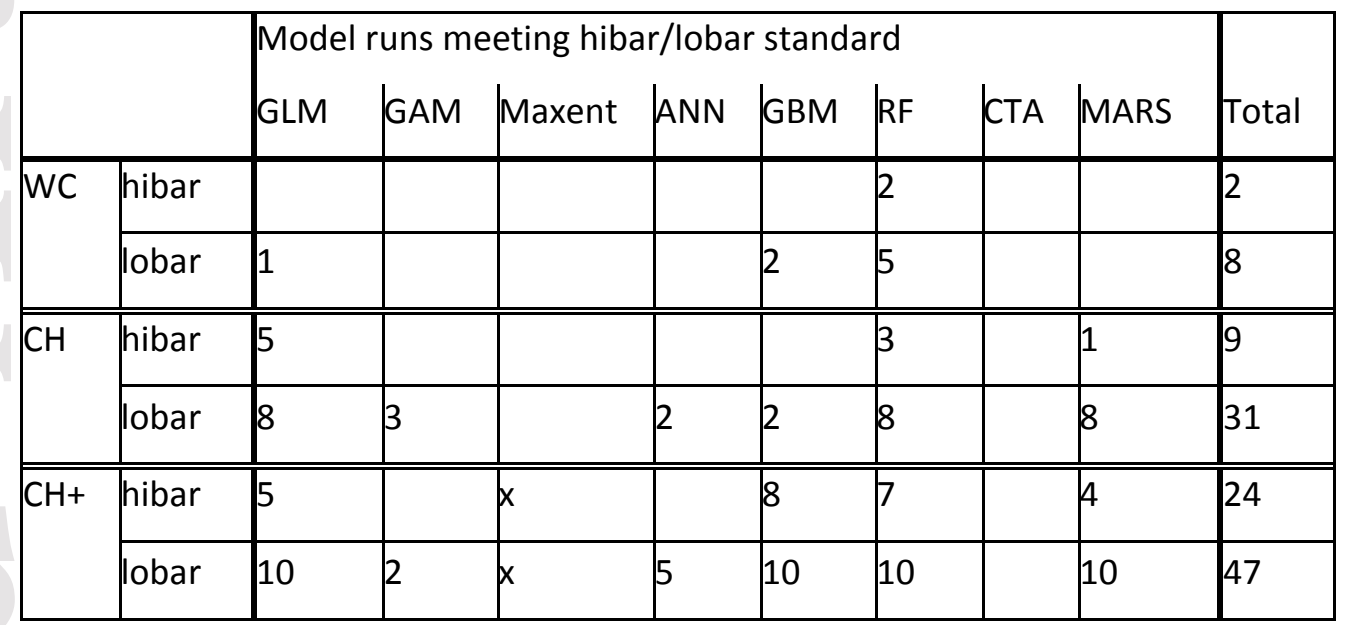

Table 1: model runs meeting 'hibar' and 'lobar' criteria for inclusion in ensembles (see figure S2 for evaluation scores of all model runs).

This article is protected by copyright. All rights reserved. 


\begin{tabular}{|c|c|c|c|c|}
\hline & Area $\left(\mathrm{km}^{2}\right)$ & Worldclim & CHELSA & CHELSA+ \\
\hline \multirow{3}{*}{$\begin{array}{l}\text { Microrefugia ( } p_{\text {occ }} \geq 75 \% \text { at } \\
\text { present and in both future } \\
\text { scenarios) }\end{array}$} & Total area & 0 & 0 & 4948.2 \\
\hline & In remnant forest & 0 & 0 & 332.5 \\
\hline & In naturally non-forested area & 0 & 0 & 2763.7 \\
\hline \multirow{3}{*}{$\begin{array}{l}\text { Moderately resilient ( } p_{\text {occ }} \geq 50 \% \\
\text { at present and in both future } \\
\text { scenarios) }\end{array}$} & Total area & 575.7 & 92212.8 & 114416.4 \\
\hline & In remnant forest & 250.1 & 13561.9 & 11438.3 \\
\hline & In naturally non-forested area & 166.1 & 7344.5 & 8704.1 \\
\hline
\end{tabular}

Table 2: area of microrefugia and moderately resilient habitat predicted by each ensemble model.

\section{Figure captions}

Figure 1: Map showing the study region's current potential vegetation (IBGE, 2004) and remnants >3ha within the Atlantic Forest domain of Paraná, Santa Catarina and Rio Grande do Sul states (Fundação SOS Mata Atlântica \& Instituto Nacional de Pesquisas Espaciais - INPE, 2015). Pink outlines show Brazilian protected areas (IUCN category la-VI), and blue outlines show designated Terras Indigenas.

Figure 2: Ensemble predictions of habitat suitability for Araucaria using Worldclim (top), CHELSA (centre) and CHELSA+ (bottom) at present (left) and in 2070 under the RCP4.5 (centre) and RCP8.5 (right) scenarios.

Figure 3: Map showing the loss of Araucaria's climatically resilient areas (from CHELSA+ ensemble model) to habitat change. Darker/redder areas are more climatically resilient, from light grey/yellow ( $p_{\text {occ }} 50 \%-75 \%$ in all three scenarios) to black/red (potential microrefugia, $p_{\text {occ }} \geq 75 \%$ in all scenarios). Areas in greyscale have lost their natural vegetation cover; those in yellow, orange and red have retained it.

Figure 4: Map showing microrefugial cells in remnant vegetation (forest in dark green, Campos in orange), patches of remnant vegetation containing $\geq 100$ microrefugial cells or which have $\geq 5 \%$ of their area covered by microrefugia (forest in pale green, Campos in buff), protected areas and designated Terras Indigenas.

This article is protected by copyright. All rights reserved. 


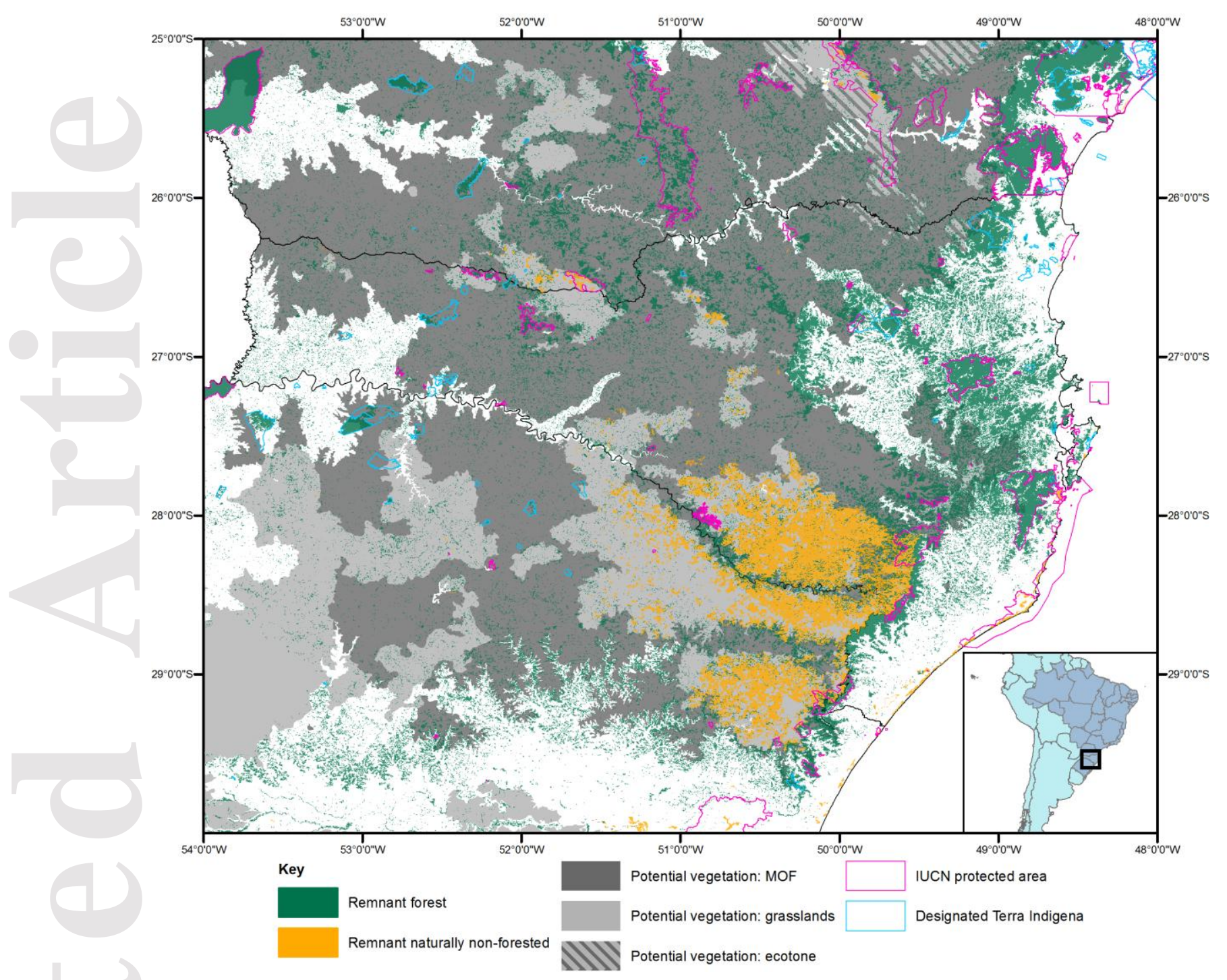

This article is protected by copyright. All rights reserved. 

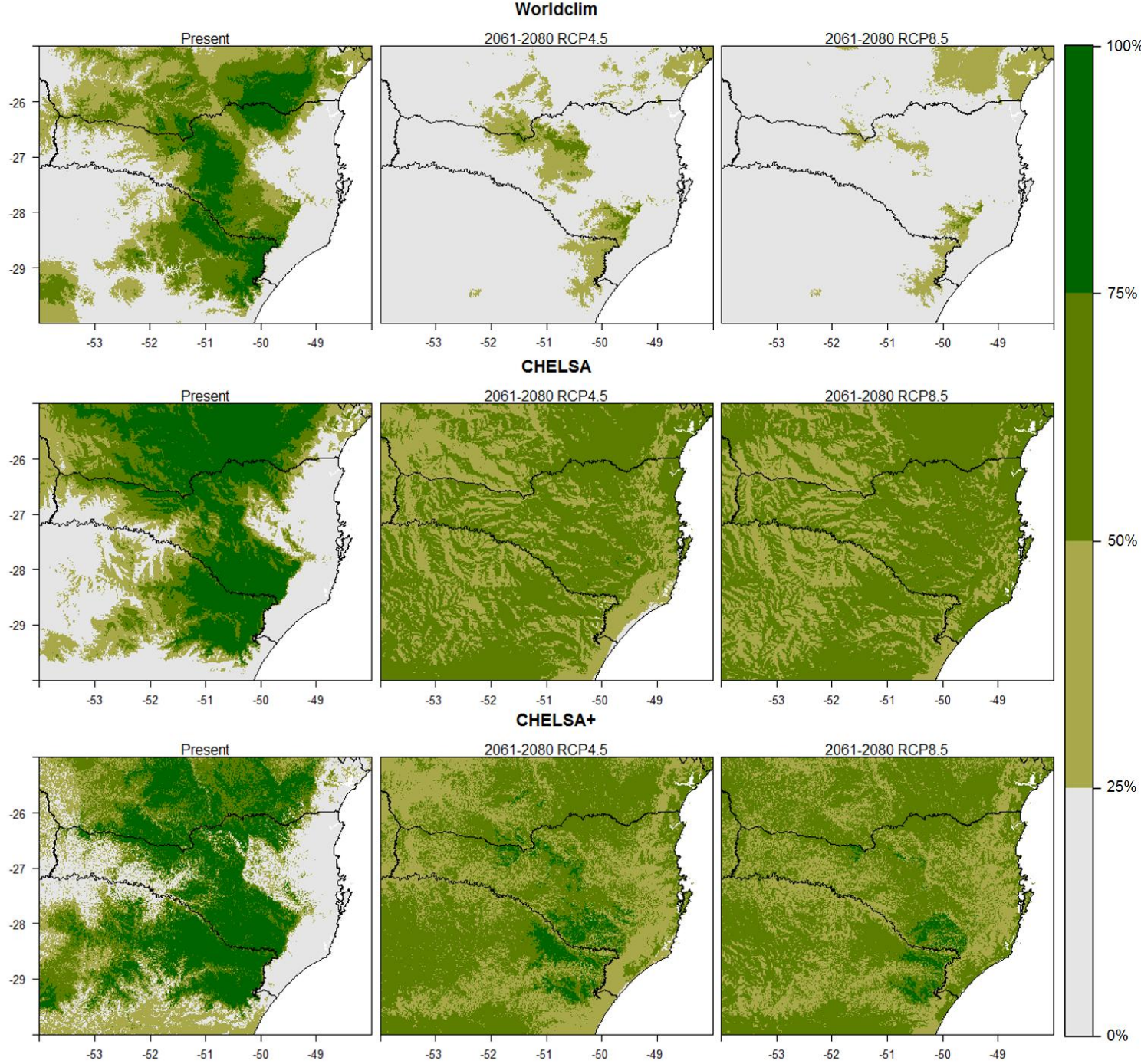

This article is protected by copyright. All rights reserved. 


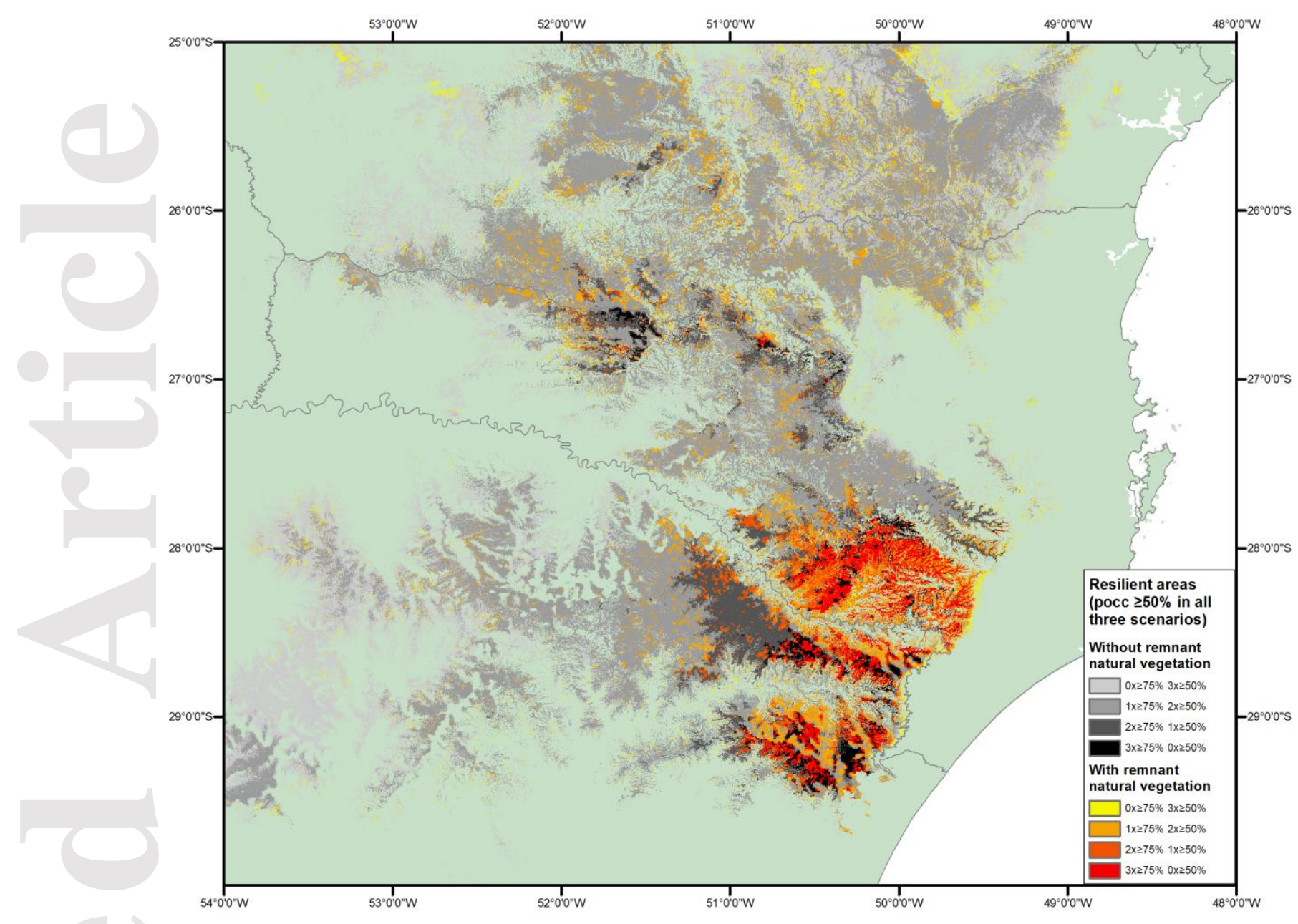

This article is protected by copyright. All rights reserved. 


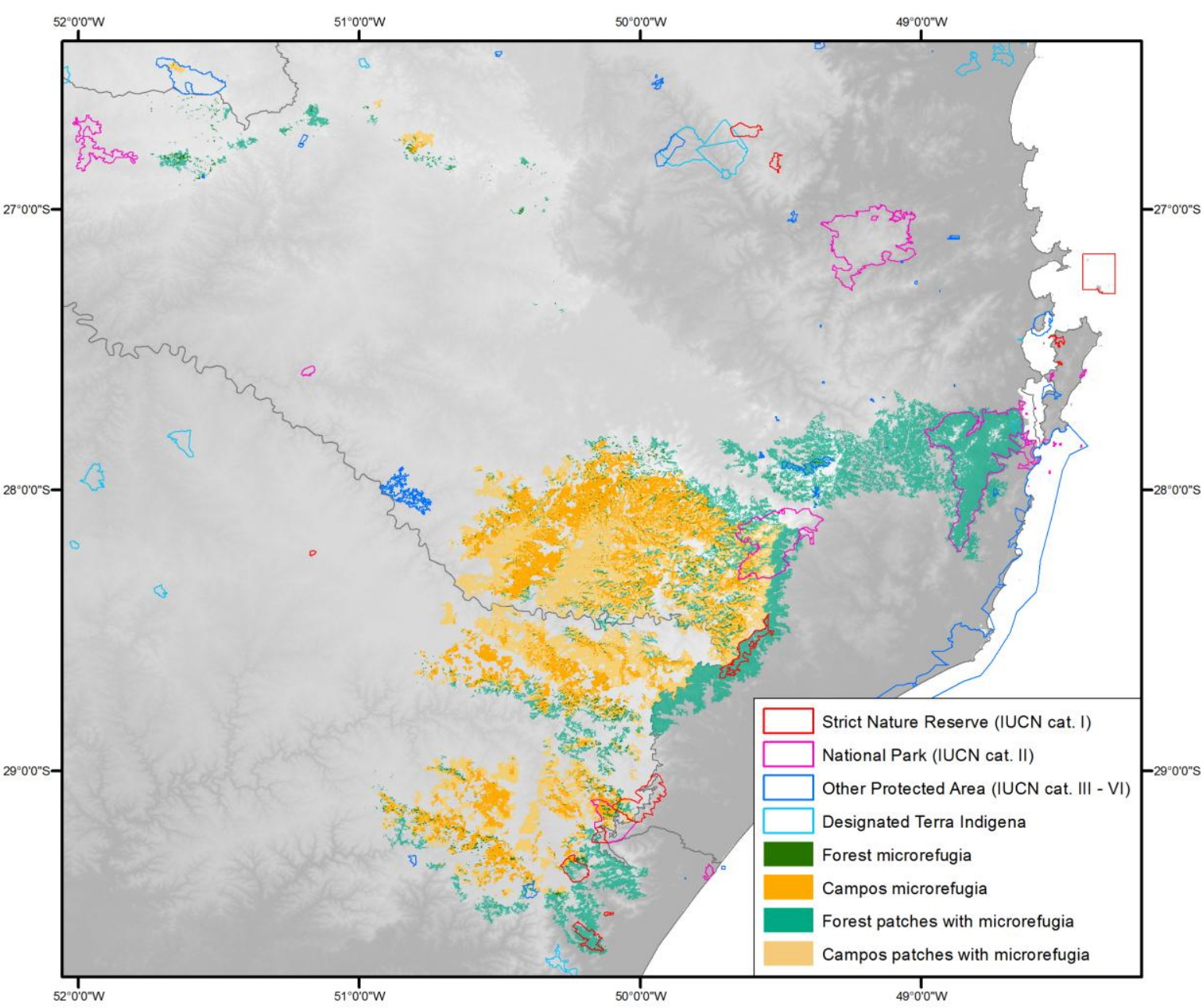

This article is protected by copyright. All rights reserved. 